\title{
Effects of progesterone injection on performance, plasma hormones and ovarian morphology of ad libitum and restricted fed broiler breeder hens
}

\author{
Mojtaba Zaghari, Reza Taherkhani and Shirin Honarbakhsh \\ Department of Animal Science, University of Tehran, Karaj31587-11167, Iran. \\ Accepted 5 October, 2009
}

\begin{abstract}
An experiment was conducted to evaluate responses of feed-satiated and feed- restricted breeder hens to daily injection of progesterone $\left(P_{4}\right)$. A total of 64 Cobb 500 hens were fed either restricted or ad libitum from 27 to 38 wk of age. Fourteen laying hens from each group were selected to conduct $\mathbf{P}_{4}$ injection assay. Half of birds in each group $(n=7)$ were injected daily by $2.5 \mathrm{mg} P_{4} / \mathrm{kg} B W$ and remaining birds were used as control. The $\mathrm{P}_{4}$ was injected subcutaneously, at the base of the neck daily (at $0900 \mathrm{~h}$ ) for $21 \mathrm{~d}$. Settable and abnormal eggs were recorded daily. Blood samples were taken just before initiation of injections, 10-d and 20-d after initiation of injection. Plasma samples were analyzed for glucose, cholesterol, triacylglycerol (TAG), $P_{4}$, estradiol $\left(E_{2}\right)$, testosterone, $T_{3}$ and $T_{4}$ concentration. Settable egg production declined following $\mathrm{P}_{4}$ injection, whereas total egg production (including soft shell egg) remain at high levels in injected birds during the first week after initiation of $\mathbf{P}_{4}$ injection. Progesterone injection in feed-satiated and feed-restricted birds resulted in ovary regression; the ovary of these birds had no hierarchical follicle. Progesterone injection increased incidence of holding hardshelled eggs in the uterus. Plasma $E_{2}$ concentrations were affected both by feeding pattern and $P_{4}$ injection. Progesterone injection depressed plasma $E_{2}$ concentration in both ad libitum and restricted fed hens. Hens with free access to feed had significantly lower plasma $E_{2}$ levels compared to restricted fed hens. Our results revealed that whereas injection of $P_{4}$ induced frequent ovulation early in the injection period in both feed- satiated and feed-restricted breeder hens; however this higher ovulation rate did not result in more settable egg production.
\end{abstract}

Key words: Progesterone, ad libitum, broiler breeder.

\section{INTRODUCTION}

Progesterone is the major hormone secreted by granulosa cells of large mature hierarchical follicles (F1) in birds. Progesterone acts at the level of the ovary and at the hypothalamus to stimulate the LH surge for ovulation. The progesterone production by $\mathrm{F} 1$ follicle peaks 6 to $8 \mathrm{~h}$ prior to ovulation (Johnson and van rinhoven, 1980) and triggers gonadotropin-releasing hormone $(\mathrm{GnRH})$ release by the hypothalamus. This in turn is followed by an increase in $\mathrm{LH}$ and $\mathrm{FSH}$ release from the anterior pituitary. The LH stimulates an even greater output of progesterone by the granulosa cells of the F1 follicle (Etches,

*Corresponding author. E-mail: rezataherkhani@yahoo.com. Tel/Fax: +982612248082.
1990), completing the positive feedback loop producing the LH peak 4 to $6 \mathrm{~h}$ prior to ovulation (Johnson et al., 1985). It has been shown that chronic or acute injection of $\mathrm{P}_{4}$ may affect bird in different manner. Administration of an acute dose of exogenous $\mathrm{P}_{4}$ has been shown to induce premature ovulation of a mature follicle at a specific time during ovulatory cycles in normal laying chicken hens (Nakada et al., 1994). Single injection of an acute dose of $\mathrm{P}_{4}$ in laying hens during the preovulatory open period has been shown to have positive effect on inducing a preovulatory LH surge and ovulation (Wilson and Sharp, 1975, 1976; Johnson et al., 1985).

However, chronic injection of $\mathrm{P}_{4}$ has been shown to increases baseline concentrations of $\mathrm{P}_{4}$ and result in arrested laying and disrupted distribution of hierarchical follicles in turkeys (Liu et al., 2001b; Bacon and Liu, 
2004). High baseline concentrations of $P_{4}$ in arrested hens might negatively feedback on the ability of the hypothalamus to secret surges of $\mathrm{GnRH}$ and subsequently surges of $\mathrm{LH}$, or on the ability of the pituitary to respond to surges of $\mathrm{GnRH}$ secretion if they occur (Liu et al., 2001b; Bacon and Liu, 2004; Liu and Bacon, 2005).

Feed satiated hens have been shown to have more large yellow follicles than their restricted fed counterparts, so the objective of this study was to evaluate the effects of injection of a high dose of $\mathrm{P}_{4}$ to simulate the essential $\mathrm{P}_{4}$ surge required for establishment of $\mathrm{LH}$ surge in feedsatiated and feed-restricted broiler breeder hens during post peak production period (when ovulation rates are decreased) on egg production, ovulation rate and ovarian morphology. We also measured plasma glucose, TAG, cholesterol, $\mathrm{P}_{4}, \mathrm{E}_{2}$, testosterone, $\mathrm{T}_{3}$ and $\mathrm{T}_{4}$ concentration to know how $\mathrm{P}_{4}$ injection affects these metabolites and hormones and consequently the bird's performance.

\section{MATERIALS AND METHODS}

\section{Birds and management}

A total of 64 Cobb 500 broiler breeder pullets with similar body weight $(2050 \pm 40 \mathrm{~g})$ were selected from a commercial flock (20 week of age) and moved to individual cages $\left(0.6 \times 0.4 ; 0.24 \mathrm{~m}^{2} /\right.$ bird) to conduct the research. Soft plastic wires were placed at cage floor to minimize bird's foot damages. Each cages had an individual feeder and a nipple waterer. Birds did not have access to each others feed. Pullets were fed restricted amounts of feed to provide a standard BW according to the Cobb Breeder Management Guide (Vantress, 2005) until 27 wk of age. Birds fed a pre-lay diet from 21 wk of age to first egg production and a broiler breeder layer diet thereafter $(2700 \mathrm{kcal}$ AMEn and $15.20 \%$ crude protein). Photostimulation occurred at 22 wk of age by providing $16 \mathrm{~h}$ of light (lights on at $0700 \mathrm{~h}$ ) and this photoperiod was maintained until experiment termination. At $27 \mathrm{wk}$ of age (50\% egg production), hens were selected on the basis of their egg production and BW and assigned to two feeding regimens from 27 to 38 wk of age: i) ad libitum feeding and ii) restricted feeding. At 38 wk of age, 14 laying hen (hens produced at least one egg during last $10 \mathrm{~d}$ ) from ad libitum and restricted fed hens were selected to conducted progesterone injection assay. At this time, hens from ad libitum group were $500 \mathrm{~g}$ heavier than their restricted counterparts. Half of birds in each group $(n=7)$ were injected daily by $2.5 \mathrm{mg} \mathrm{P} / \mathrm{kg} \mathrm{BW}$ and remaining birds were used as control. The $\mathrm{P}_{4}$ injections were injected subcutaneously, at the base of the neck, daily (at $0900 \mathrm{~h}$ ) for $21 \mathrm{~d}$. The $\mathrm{P}_{4}$ vials were diluted by canola oil and $0.15 \mathrm{ml} / \mathrm{kg} \mathrm{BW}$ were injected each time.

\section{Laying performance}

Eggs were manually collected 2 times per day. Hen-day egg production was calculated weekly from daily egg counts and the numbers of abnormally double-yolked and soft shell egg were also recorded daily. Ovulation rate was calculated as (normal eggs + soft shell eggs $+2 \times$ double yolk eggs) .

\section{Necropsy and tissue collection}

At the end of experimental period, 4 hens per treatment were slaughtered for necropsy. Liver, abdominal fat pad and ovary were collected at necropsy. Weight of liver, ovary and abdominal fat pad were divided by $(\mathrm{BW} / 100)$ to estimate their fractional contribution. Ovaries were weighed (after removing hierarchical follicles) and follicles were classified into 3 groups: hierarchical follicles (large yellow follicles, $>8 \mathrm{~mm}$ ), small yellow follicles (2 to $8 \mathrm{~mm}$ ) and large white follicles ( 2 to $5 \mathrm{~mm}$ ) according to the system devised by Gilbert et al. (1983).

\section{Blood sampling}

To evaluate plasma hormones and metabolites, first bleeding was carried out before initiation of injections and two subsequent bleedings were repeated every $10 \mathrm{~d}$. Blood samples were obtained just before $\mathrm{P}_{4}$ injection. Blood samples were collected in EDTA coated tubes from the brachial vein of all hens per group. Blood samples were immediately centrifuged at $2000 \times \mathrm{g}$ for $15 \mathrm{~min}$ to collect blood plasma. Plasma samples were stored at $-20^{\circ} \mathrm{C}$ until assayed for glucose, TAG, cholesterol, as well as $\mathrm{T}_{3}, \mathrm{~T}_{4}$, progesterone, estradiol and testosterone.

\section{Plasma metabolites and hormones}

Plasma glucose, total triacylglycerol and cholesterol $(\mathrm{CHO})$ were determined enzymatically using an automated analyzer (Hitachi 902, Japan). Specific radioimmunoassay was used to determine plasma hormone concentrations. All samples were analyzed within 1 assay in order to avoid inter-assay variations. Plasma $P_{4}$ and $E_{2}$ were determined by commercial RIA kits (ICN, Biochemichals, Cleveland, $\mathrm{OH}$ ) with intra-assay $\mathrm{CV}$ of 6.46 and 7.15, respectively. The use of the $\mathrm{P}_{4}$ and $\mathrm{E}_{2}$ kits for chicken has previously validated by Onagbesan et al. (2006). Plasma testosterone was determined by using RIA kit (DRG, Germany) according to manufacturer's procedure with an intraassay $\mathrm{CV}$ of 6.39 . Total $\mathrm{T}_{3}$ and $\mathrm{T}_{4}$ concentration were determined using commercial RIA kits (DRG, Germany). The intra-assay $C V$ for $T_{3}$ and $T_{4}$ were 3.58 and 4.62 , respectively.

\section{Statistical analysis}

The experimental birds were housed in individual cages. The experimental design was completely randomized with factorial arrangement using individual broiler breeder hens as experimental unit. There were 2 method of feed allocation with or without $P_{4}$ injection. Performance data as well as plasma metabolites and hormones data were analyzed as repeated measures using Proc Mixed of SAS software (SAS Institute, Cary, NC). Differences between means were evaluated using least square means procedure. Data obtained in necropsy were analyzed using GLM procedure of SAS software and means were separated by Duncan multiple range test. Significant differences were considered to be $P<0.05$.

\section{RESULTS}

\section{Performance data}

Progesterone injection significantly affected settable egg production. Progesterone injected bird produced less settable egg compared to non-injected birds both in restricted and ad libitum fed groups (Figure 1). Drop in egg production continued through experimental period and reached to zero, 3 wk after $\mathrm{P}_{4}$ injections. Egg production 


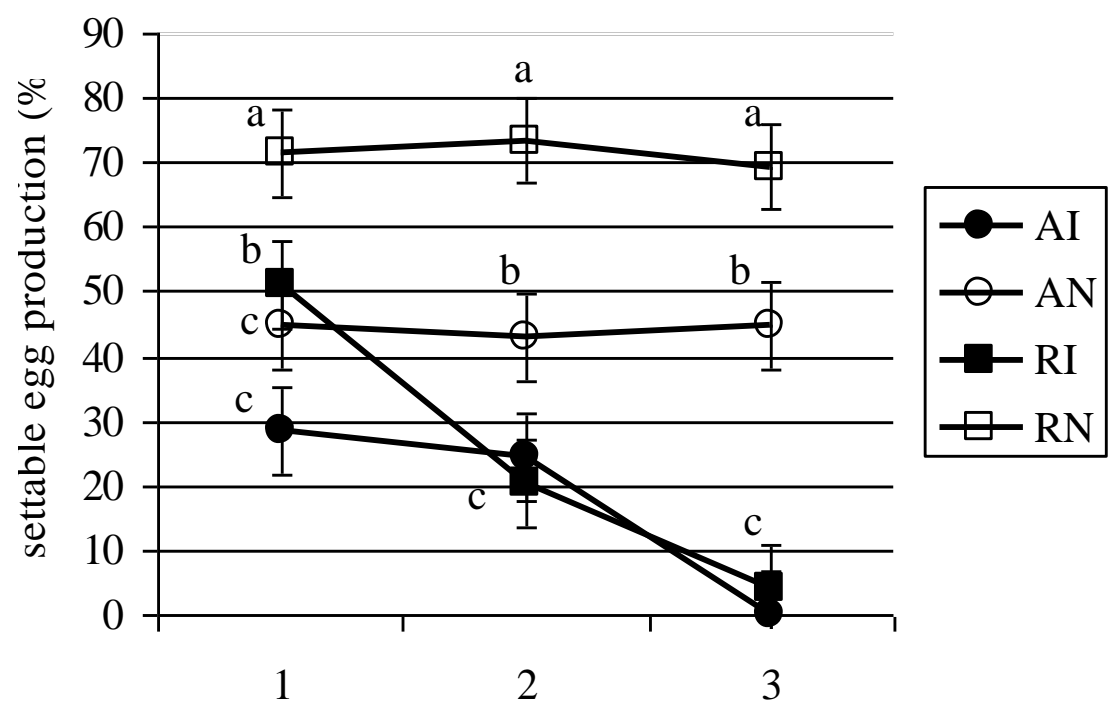

\section{Week after initiation of injections}

Figure 1. Settable egg production in ad libitum fed with (AI) or without (AN) $\mathrm{P}_{4}$ injection and in restricted fed hens with (RI) or without (RN) $P_{4}$ injection. Data are means \pm SEM. a-c Data points with different letters are significantly different at the age of the hens $(P<0.05)$.

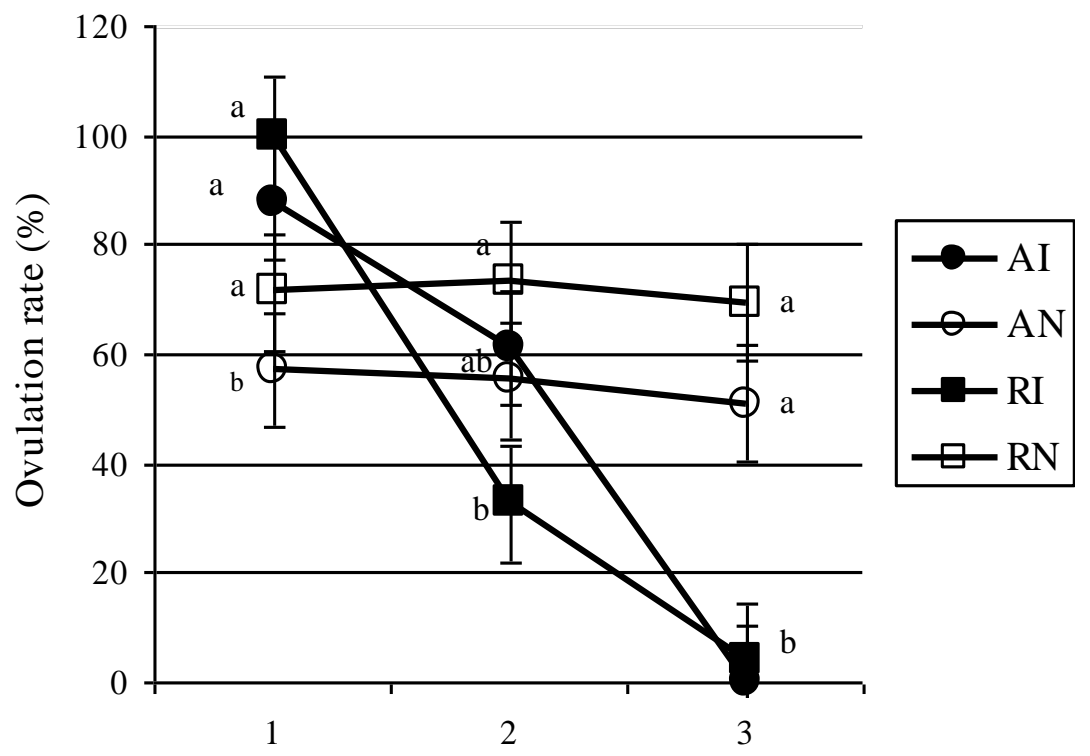

week after initiation of injections

Figure 2. Ovulation rate (\%) in ad libitum fed with (AI) or without (AN) $\mathrm{P}_{4}$ injection and in restricted fed hens with $(\mathrm{RI})$ or without $(R N) \mathrm{P}_{4}$ injection. Data are means \pm SEM. a-b Data points with different letters are significantly different at the age of the hens $(P<0.05)$.

in ad libitum non-injected birds was significantly lower than their restricted fed counterparts.

Ovulation rate in hens from different treatment are presented in Figure 2. Although egg production declined following $\mathrm{P}_{4}$ injection, however ovulation rate remain at high levels in injected birds in the first week after initiation of $\mathrm{P}_{4}$ injection. Ad libitum fed hens without $\mathrm{P}_{4}$ injection had significantly lower ovulation rate compared to birds 
from remaining treatment. Whereas ovulation rate in injected birds was numerically higher than non-injected birds in the first week after initiation of $\mathrm{P}_{4}$ injection, a dramatic decline occurred during the second and third wk post $P_{4}$ injections. The decline in ovulation rate in injected birds was more severe in restricted birds compared to ad libitum fed hens.

The number of soft shell eggs in $\mathrm{P}_{4}$ injected birds was significantly higher than their non-injected counterparts in the first week post injections; however along with decline in ovulation rate in the later weeks, numbers of soft shell eggs tend to decrease (Table 1).

Hens with $\mathrm{P}_{4}$ injection produced more soft shell eggs compared to non-injected hens (Table 1). Ad libitum fed birds also produced more $(P<0.05)$ double yolk eggs than restricted fed hens (Table 1 ).

\section{Carcass and ovary data}

Abdominal fad pad fractional weight in ad libitum fed birds were significantly higher than restricted fed birds (Table 1); furthermore, feed-satiated hens had significantly heavier liver compared to feed-restricted birds. However $\mathrm{P}_{4}$ injection had no significant effect on abdominal fat and liver fractional weight (Table 1).

Ovary fractional weight in hens with $\mathrm{P}_{4}$ injection both in feed-satiated and feed-restricted birds were significantly lower than non-injected birds (Table 1).

Progesterone injection in feed-satiated and feed-restricted birds resulted in ovary regression; the ovary of these birds had no hierarchical follicle, SYF and also LWF (Table 1). The numbers of LYF in ad libitum fed hens were significantly higher than feed-restricted birds. Progesterone injection increased incidence of holding hardshelled eggs in the uterus. Three hens from ad libitum and 2 hens from restricted fed birds (42 and $28 \%$ of necropsied birds, respectively) hold a hard-shelled egg in their uterus (data not shown).

\section{Hormones and metabolites}

Plasma glucose, TAG and $\mathrm{CHO}$ concentrations of hens from different treatments are presented in Table 2. Ad libitum fed hens had significantly $(P<0.0001)$ higher plasma glucose, TAG and $\mathrm{CHO}$ levels than their restrictted fed counterparts. However, $\mathrm{P}_{4}$ injection did not have any significant effect on these metabolites.

Progesterone injection significantly $(P<0.0001)$ reduced plasma $\mathrm{P}_{4}$ concentration both in ad libitum or restricted fed birds 10 and $20 \mathrm{~d}$ after initiation of $\mathrm{P}_{4}$ injection (Figure 3). Plasma $\mathrm{P}_{4}$ levels were not different between feed-satiated and feed-restricted birds.

Plasma $E_{2}$ concentrations were affected both by feeding pattern and $\mathrm{P}_{4}$ injection (Figure 4). Progesterone injection depressed $(P<0.0001)$ plasma $E_{2}$ concentration in both ad libitum and restricted fed hens. Hens with free access to feed had significantly lower $(\mathrm{P}<0.0001)$ plas$\mathrm{ma} \mathrm{E}_{2}$ levels compared to restricted fed hens.

Plasma testosterone concentrations of hens from different treatments are presented in figure 5. Ad libitum fed birds had significantly higher $(P<0.0001)$ plasma testosterone levels compared to their restricted fed counterparts. Hens with $\mathrm{P}_{4}$ injection had significantly lower $(\mathrm{P}$ $<0.001$ ) plasma testosterone concentrations than noninjected birds.

Ad libitum fed birds had significantly higher $(\mathrm{P}<$ 0.0001) plasma $T_{3}$ (Figure 6) and lower $(P<0.0001)$ plasma $\mathrm{T}_{4}$ concentration (Figure 7 ) than their restricted fed counterparts. Progesterone injection did not change plasma $T_{3}$ or $T_{4}$ concentration neither in ad libitum fed hens nor in restricted fed birds.

\section{DISCUSSION}

Progesterone acts on ovary and hypothalamus to stimulate the $\mathrm{LH}$ surge for ovulation. The rise in progesterone concentration stimulates a rise in $\mathrm{LH}$ concentration, which in turn stimulates a further rise in progesterone. This positive feedback loop is what causes the progesterone and ultimately LH surge (Johnson et al., 1985).

The current study was designed to examine the effects of a simulated progesterone surge (by injection of a high dose of $\mathrm{P}_{4}$ ) on broiler breeder hens performance, ovary morphology, plasma metabolites and hormones concentrations in either feed-satiated or feed-restricted hens. Although $\mathrm{P}_{4}$ injection resulted in increased ovulation rate during the first week post injections, however, settable egg number decreased along with initiation of injections because of high number of soft shell and double yolk egg production. During the second and third wk after injections both ovulation rate and egg production decreased in feed-satiated or feed-restricted birds. Increased ovulation rate during first week after injection may be due to simultaneity of $\mathrm{P}_{4}$ injection with open period of $\mathrm{LH}$. High dose of $\mathrm{P}_{4}$ acts as a progesterone surge and drives follicles to ovulation. Inability of oviduct to direct all ovulated follicles resulted in higher incidence of soft shell and double yolk eggs. Liu and Bacon (2005) observed higher incidence of soft shell egg after $\mathrm{P}_{4}$ injections in broiler breeder. Similar to results obtained in the current study, egg production decreased after $\mathrm{P}_{4}$ injection in turkey (Bacon and Liu, 2004), broiler breeder (Liu and Bacon, 2005) and in Japanese quail (Tell et al., 1999; Liu and Bacon, 2004). Egg production ceased 3 wk after injecting daily $\mathrm{P}_{4}$. Necropsy data shown a regressed ovary with no LYF, SYF or LWF in all hens with progesterone injection. Taken together, these data suggest that $P_{4}$ treatment has a strong negative effect on egg production rate and hierarchical follicular maintenance and development. Liu and Bacon (2005) came to similar conclusion.

Ad libitum fed broiler breeders are known to have more 
Table 1. Effect of $\mathrm{P}_{4}$ injection in restricted fed and ad libitum fed hens on carcass, ovary and egg parameters.

\begin{tabular}{|c|c|c|c|c|c|c|c|c|c|}
\hline Treatment & & $\begin{array}{c}\text { Abdominal } \\
\text { fat weight (\%) }\end{array}$ & $\begin{array}{c}\text { Liver } \\
\text { weight(\%) } \\
\end{array}$ & $\begin{array}{c}\text { Ovary } \\
\text { weight(\%) }\end{array}$ & $\begin{array}{l}\text { LYF per } \\
\text { ovary }\end{array}$ & $\begin{array}{c}\text { SYF per } \\
\text { ovary }\end{array}$ & $\begin{array}{c}\text { LWF per } \\
\text { ovary }\end{array}$ & $\begin{array}{c}\text { Double yolk } \\
\text { egg (\%) }\end{array}$ & $\begin{array}{c}\text { Soft shell } \\
\text { egg (\%) }\end{array}$ \\
\hline \multicolumn{10}{|l|}{ Main effect } \\
\hline Feeding pattern & $\begin{array}{l}\text { Ad libitum } \\
\text { restricted }\end{array}$ & $\begin{array}{l}2.47^{\mathrm{a}} \\
1.16^{\mathrm{b}}\end{array}$ & $\begin{array}{l}2.08^{\mathrm{a}} \\
1.45^{\mathrm{b}}\end{array}$ & $\begin{array}{l}1.03 \\
0.97 \\
\end{array}$ & $\begin{array}{l}4.75^{\mathrm{a}} \\
2.25^{\mathrm{b}}\end{array}$ & $\begin{array}{l}5.12 \\
6.25 \\
\end{array}$ & $\begin{array}{l}11.50 \\
15.25 \\
\end{array}$ & $\begin{array}{l}5.10^{\mathrm{a}} \\
1.36^{\mathrm{b}}\end{array}$ & $\begin{array}{c}10.88^{\mathrm{a}} \\
5.10^{\mathrm{b}}\end{array}$ \\
\hline $\mathrm{P}_{4}$ injection & $\begin{array}{l}\text { injected } \\
\text { Non injected }\end{array}$ & $\begin{array}{l}1.68 \\
1.68 \\
\end{array}$ & $\begin{array}{l}1.78 \\
1.75 \\
\end{array}$ & $\begin{array}{l}0.45^{\mathrm{b}} \\
1.55^{\mathrm{a}} \\
\end{array}$ & $\begin{array}{l}0.00^{b} \\
7.00^{a} \\
\end{array}$ & $\begin{array}{c}0.00^{\mathrm{b}} \\
11.37^{\mathrm{a}} \\
\end{array}$ & $\begin{array}{c}0.00^{\mathrm{b}} \\
26.75^{\mathrm{a}} \\
\end{array}$ & $\begin{array}{l}4.76^{\mathrm{a}} \\
1.70^{\mathrm{b}}\end{array}$ & $\begin{array}{c}14.28^{\mathrm{a}} \\
1.70^{\mathrm{b}}\end{array}$ \\
\hline Feeding pattern & $\mathbf{P}_{4}$ injection & & & & & & & & \\
\hline $\begin{array}{l}\text { Ad libitum } \\
\text { Ad libitum } \\
\text { Restricted } \\
\text { Restricted } \\
\end{array}$ & $\begin{array}{l}\text { injected } \\
\text { Non injected } \\
\text { injected } \\
\text { Non injected } \\
\end{array}$ & $\begin{array}{l}2.56^{\mathrm{a}} \\
2.39^{\mathrm{a}} \\
1.34^{\mathrm{b}} \\
0.98^{\mathrm{b}} \\
\end{array}$ & $\begin{array}{l}2.11^{\mathrm{a}} \\
2.06^{\mathrm{a}} \\
1.40^{\mathrm{b}} \\
1.50^{\mathrm{b}} \\
\end{array}$ & $\begin{array}{l}0.35^{\mathrm{b}} \\
1.71^{\mathrm{a}} \\
0.55^{\mathrm{b}} \\
1.40^{\mathrm{a}} \\
\end{array}$ & $\begin{array}{l}0.00^{c} \\
9.50^{a} \\
0.00^{c} \\
4.50^{b} \\
\end{array}$ & $\begin{array}{c}0.00^{\mathrm{b}} \\
10.25^{\mathrm{a}} \\
0.00^{\mathrm{b}} \\
12.50^{\mathrm{a}}\end{array}$ & $\begin{array}{c}0.00^{\mathrm{b}} \\
23.00^{\mathrm{a}} \\
0.00^{\mathrm{b}} \\
30.00^{\mathrm{a}}\end{array}$ & $\begin{array}{l}6.80^{\mathrm{a}} \\
3.40^{\mathrm{b}} \\
3.40^{\mathrm{b}} \\
0.00^{\mathrm{b}} \\
\end{array}$ & $\begin{array}{c}18.36^{\mathrm{a}} \\
3.40^{\mathrm{b}} \\
13.60^{\mathrm{a}} \\
0.00^{\mathrm{b}} \\
\end{array}$ \\
\hline Pooled SEM & & 0.25 & 0.09 & 0.12 & 0.54 & 1.32 & 4.09 & 2.45 & 3.14 \\
\hline
\end{tabular}

Table 2.Glucose, cholesterol and triacyglycerol concentration in restricted fed or ad libitum fed hens with or without $\mathrm{P}_{4}$ injection.

\begin{tabular}{|c|c|c|c|c|c|c|c|c|c|c|}
\hline & & \multicolumn{3}{|c|}{ Glucose (mg/dl) } & \multicolumn{3}{|c|}{ Cholesterol (mg/dl) } & \multicolumn{3}{|c|}{ Triacylglycerol (mg/dl) } \\
\hline \multicolumn{2}{|c|}{ Treatment } & before & 10d after & $20 \mathrm{~d}$ after & before & 10d after & $20 \mathrm{~d}$ after & before & $10 \mathrm{~d}$ after & $20 \mathrm{~d}$ after \\
\hline Ad libitum & Injected & $296.14^{\mathrm{a}}$ & $295.28^{a}$ & $293.00^{\mathrm{a}}$ & $172.96^{\mathrm{a}}$ & $183.74^{\mathrm{a}}$ & $187.31^{\mathrm{a}}$ & $1753.31^{a}$ & $1742.47^{\mathrm{a}}$ & $1736.64^{\mathrm{a}}$ \\
\hline Ad libitum & Non injected & $298.22^{a}$ & $296.44^{\mathrm{a}}$ & $298.64^{a}$ & $174.62^{\mathrm{a}}$ & $187.16^{\mathrm{a}}$ & $184.60^{\mathrm{a}}$ & $1772.53^{\mathrm{a}}$ & $1715.86^{\mathrm{a}}$ & $1786.29^{a}$ \\
\hline Restricted & Injected & $217.78^{b}$ & $217.62^{b}$ & $217.59^{b}$ & $114.76^{\mathrm{b}}$ & $123.47^{\mathrm{b}}$ & $121.42^{b}$ & $1341.61^{b}$ & $1309.44^{\mathrm{b}}$ & $1305.09^{b}$ \\
\hline Restricted & Non injected & $218.60^{b}$ & $219.39^{b}$ & $216.61^{b}$ & $115.83^{b}$ & $117.85^{b}$ & $123.14^{b}$ & $1330.88^{b}$ & $1305.09^{b}$ & $1246.80^{b}$ \\
\hline \multicolumn{2}{|c|}{ Pooled SEM } & 7.69 & 7.53 & 7.68 & 0.24 & 0.26 & 0.25 & 41.95 & 41.37 & 49.16 \\
\hline
\end{tabular}

hierarchical follicles than their restricted fed counterparts (Yu et al., 1992; Chen et al., 2006; Sun et al., 2006). It seems that higher ovulation rate in ad libitum fed hens with $\mathrm{P}_{4}$ injection compared to restricted fed birds may be due to more LYF number in their ovary.

Progesterone injection significantly lowered $E_{2}$ concentration both in feed-satiated and feedrestricted hens. Plasma concentrations of $E_{2}$ are increased after follicle stimulating hormone (FSH) injection in laying hens late in the reproductive period (Palmer and Bahr, 1992), suggesting that the secretion of FSH is also decreased after $\mathrm{P}_{4}$ injection. Liu and Bacon (2005) reported a decline in $\mathrm{LH}$ concentration after $\mathrm{P}_{4}$ injection. Taken together, these data suggest $\mathrm{P}_{4}$ injection may have negative effect on secretion of $\mathrm{GnRH}$. High concentrations of $E_{2}$ are required to sensitize the hypothalamic pituitary axis to the positive feed back effects of progesterone (Wilson and Sharp, 1976) to stimulate vitellogenin formation in the liver (Redshaw and Foliett, 1972), to regulate calcium metabolism (Etches, 1987), to stimulate and maintain a functional oviduct and to maintain secondary sexual characteristic. The lower concentration of $E_{2}$ may thus lead to regression of the oviduct and impaired follicles development after 


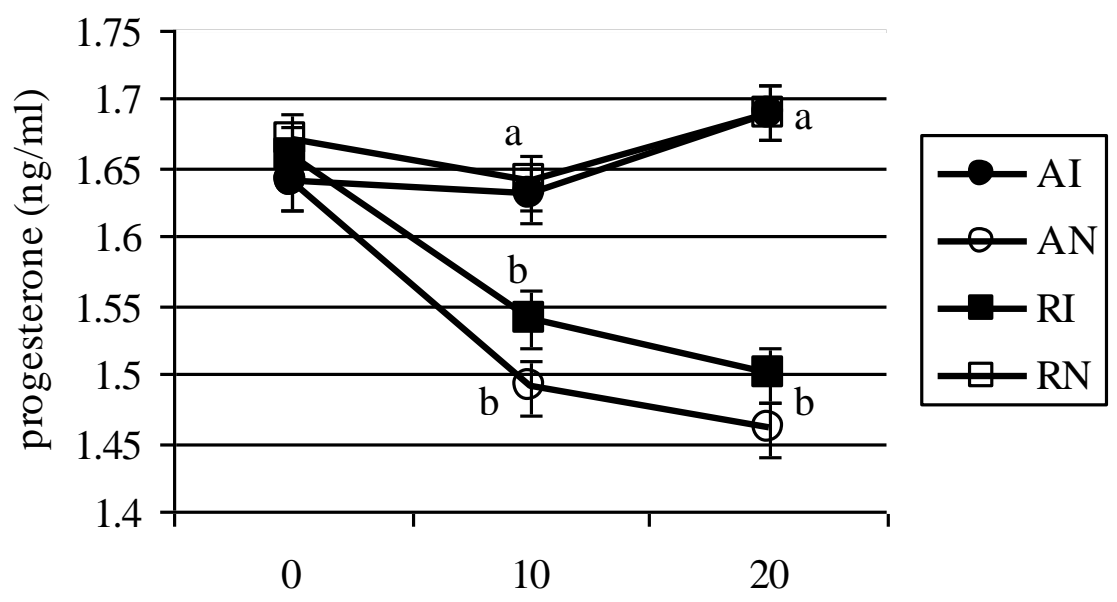

days after initiation of injections

Figure 3. Progesterone concentration in ad libitum fed with (AI) or without (AN) $\mathrm{P}_{4}$ injection and in restricted fed hens with $(R I)$ or without $(R N) P_{4}$ injection. Data are means \pm SEM. a-b Data points with different letters are significantly different at the age of the hens $(P<0.05)$.

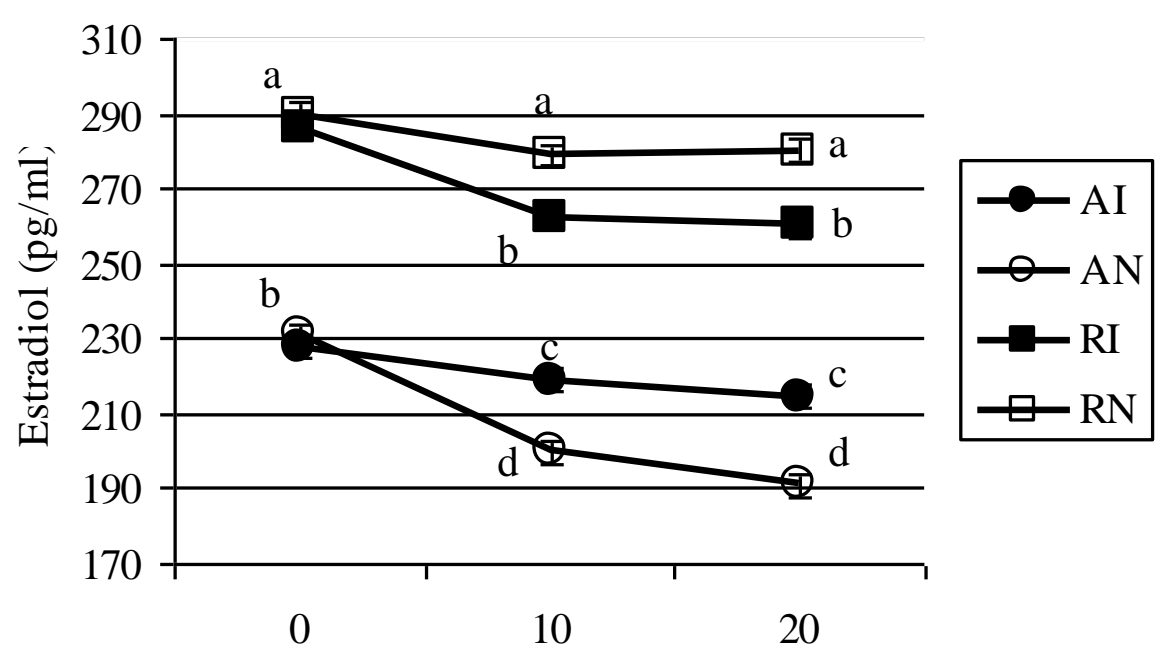

Days after initiation of injections

Figure 4. Estradiol concentration in ad libitum fed with (AI) or without (AN) $\mathrm{P}_{4}$ injection and in restricted fed hens with $(\mathrm{RI})$ or without $(\mathrm{RN}) \mathrm{P}_{4}$ injection. Data are means \pm SEM. a-c Data points with different letters are significantly different at the age of the hens $(P$ $<0.05)$.

$\mathrm{P}_{4}$ injection. Similar to our results, Liu and Bacon (2005) observed a depression in plasma $\mathrm{E}_{2}$ along with regressed ovary after injection of $\mathrm{P}_{4}$ in broiler breeder hens. Lower $\mathrm{E}_{2}$ concentration of ad libitum fed hens compared to restricted fed hens observed in this research is in agreement with Onagbesan et al. (2006).

Plasma $\mathrm{P}_{4}$ concentrations in hens with daily injection of $\mathrm{P}_{4}$ decreased 10 and $20 \mathrm{~d}$ after initiation of injections. Injection of acute dose of $\mathrm{P}_{4}$ will result in higher $\mathrm{P}_{4}$ surge concentration which in turn lowers $\mathrm{P}_{4}$ production through negatively affecting $\mathrm{LH}$ and FSH production. Liu and Bacon (2005) concluded that higher $\mathrm{P}_{4}$ surge concentration and lower $\mathrm{LH}$ baseline concentration may be associated with decline in egg production in $\mathrm{P}_{4}$ injected breeder hens. Progesterone concentration decreased following $\mathrm{P}_{4}$ injections in broiler breeder hens in the study of Liu and Bacon (2005).

Besides $E_{2}$ and $P_{4}$, progesterone injection lowered plasma testosterone levels both in feed-satiated and restricted fed hens. It seems that $P_{4}$ injection negatively 


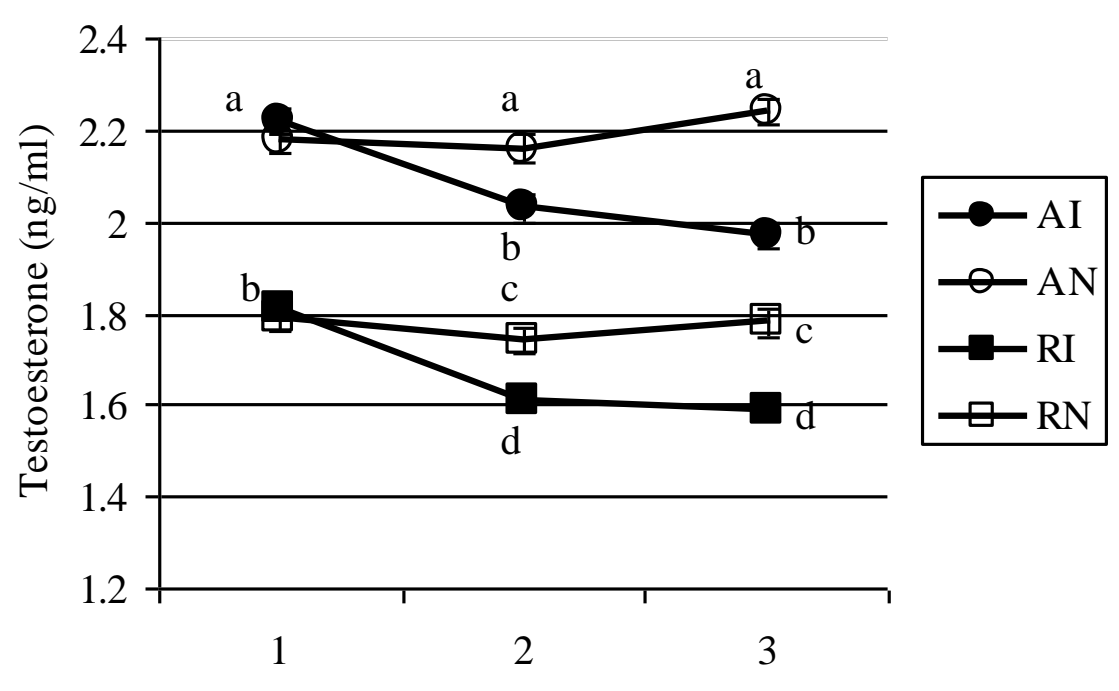

Week after initiation of injection

Figure 5. Testosterone concentration in ad libitum fed with (Al) or without (AN) $\mathrm{P}_{4}$ injection and in restricted fed hens with (RI) or without (RN) $\mathrm{P}_{4}$ injection. Data are means \pm SEM. a-d Data points with different letters are significantly different at the age of the hens $(P<0.05)$.

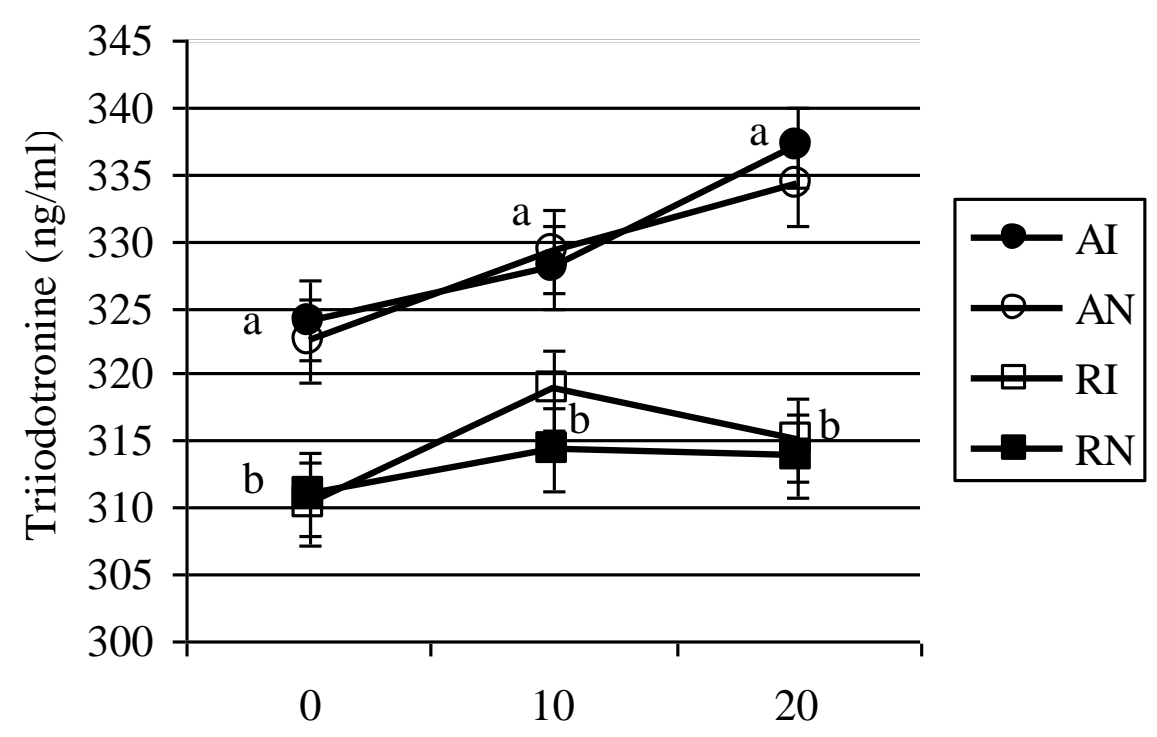

Davs after initiation of iniections

Figure 6. Plasma $T_{3}$ concentration in ad libitum fed with $(\mathrm{Al})$ or without (AN) $\mathrm{P}_{4}$ injection and in restricted fed hens with $(R I)$ or without $(R N) P_{4}$ injection. Data are means \pm SEM. $a-b$ Data points with different letters are significantly different at the age of the hens $(P<0.05)$.

affect ovarian steroidogenesis.

Whereas $\mathrm{P}_{4}$ injection had no significant effect on plasma metabolites, feeding pattern significantly affected plasma glucose, TAG and $\mathrm{CHO}$. Ad libitum fed hens had higher levels of plasma glucose, TAG and $\mathrm{CHO}$ compared to restricted fed birds. These results are consistent with those reported by Chen et al. (2006) and Sun et al. (2006).

Progesterone injection increased incidence of holding a hard-shelled eggs in the uterus. Similar to results observed in our study, Liu and Bacon (2005) reported a high incidence of holding hard-shelled eggs in broiler 


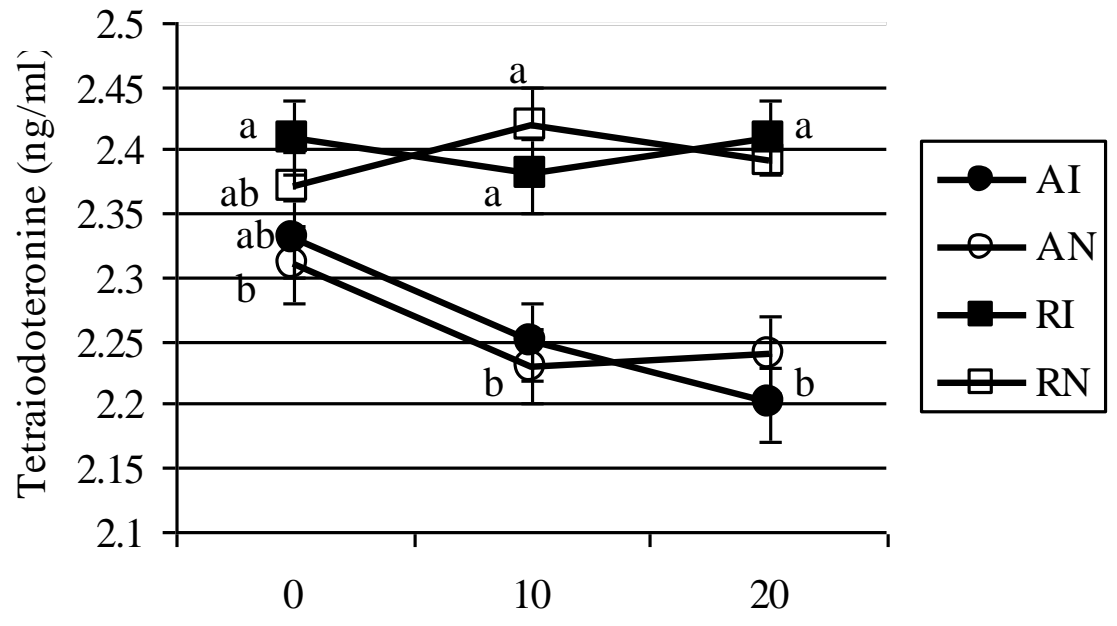

Days after initiation of injections

Figure 7. Plasma $T_{4}$ concentration in ad libitum fed with $(\mathrm{Al})$ or without $(\mathrm{AN}) \mathrm{P}_{4}$ injection and in restricted fed hens with $(R I)$ or without $(R N) P_{4}$ injection. Data are means \pm SEM. $a-b$ Data points with different letters are significantly different at the age of the hens $(P<0.05)$.

breeder hen's uterus. Holding a hard-shelled egg in the uterus was also induced by exogenous $\mathrm{P}_{4}$ in turkey (Bacon and Liu, 2004) and quail hens (Lin et al., 1993; Tell et al., 1999; Liu and Bacon, 2004), suggesting that $P_{4}$ may be associated with inhibition of muscular contraction of the uterus at oviposition in these species.

Progesterone injection had no significant effect on plasma $T_{3}$ and $T_{4}$ concentrations; however ad libitum fed hens had lower $T_{3}$ and higher $T_{4}$ level compared to restricted fed hens. Numerous studies suggest that feed restriction decrease $T_{3}$ and increase $T_{4}$ levels in broiler breeders (Darras et al., 1995; Bruggeman et al., 1997).

In conclusion, whereas injecting an high dose of $\mathrm{P}_{4}$ once a day for 3 wk induced frequent ovulation early in the injection period in both feed-satiated and feed-restricted breeder hens; however this higher ovulation rate did not result in more settable egg production. Egg production decreased with $\mathrm{P}_{4}$ injection and ceased at the termination of experiment. Decreased egg production in $P_{4}$ injected bird was associated with lower levels of sex steroid hormones $\left(\mathrm{P}_{4}, \mathrm{E}_{2}\right.$ and testosterone) and regressed ovary. Progesterone injection increased numbers of hens holding a hard-shelled egg in their uterus. Progesterone injection had no significant effect on glucose home ostasis and lipid metabolism. Restricted fed and laying ad libitum fed breeder hens respond in a similar way to a high dose of $\mathrm{P}_{4}$ injection.

\section{REFERENCES}

Bacon WL, Liu HK (2004). Progesterone injection and egg production in turkey hens. Biol. Reprod. 71: 878-886.

Bruggeman V, Vanmontfort D, Renaville R, Portetelle D, Decuypere E (1997). The effect of food intake from two weeks of age to sexual maturity on plasma growth hormone, insulin-like growth factor-I, insulin-like growth factor-binding proteins, and thyroid hormones in female broiler breeder chickens. Gen. Comp. Endocrinol. 107: 212220.

Chen SE, Mc Murty JP, Walzem RL (2006). Overfeeding-induced ovarian dysfunction in broiler breeder hens is associated with lipotoxicity. Poult. Sci. 86: 70-81.

Cobb-Vantress Inc., Cobb breeder management guide (2005) CobbVantress Inc., Siloam Springs, AR.

Darras VM, Cokelaere M, Dewil E, Arnouts S, Decuypere E and Kuhn ER (1995). Partial food restriction increases hepatic inner ring deiodinating activity in the chicken and the rat. Gen. Comp. Endocrinol. 100: 334-338.

Etches RJ (1978). Calcium logistics in the hen. J. Nutr. 117: 619-624.

Etches RJ (1990). The ovulatory cycle of the hen. CRC Crit. Rev. Poult. Biol. pp. 293-318.

Gilbert AB, Perry MM, Waddington D, Hardie MA (1983). Role of atresia in establishing the follicular hierarchy in the ovary of the domestic hen (Gallus domesticus). J. Reprod. Fertil. 69: 221-227.

Johnson AL, Van Tienhoven A (1980) Plasma concentrations of sex steroids and LH during the ovulatory cycle of the hen, Gallus domesticus. Biol. Reprod. 23:386-393.

Johnson PA, Johnson AL, Van Tienhoven A (1985). Evidence for a positive feedback interaction between progesterone and luteinizing hormone in the induction of ovulation in the hen, Gallus domesticus. Gen. Comp. Endocrinol. 58: 478-485.

Liu HK, Bacon WL (2004). Effect of chronic progesterone injection on egg production of Japanese quail. Poult. Sci. 83: 2051-2058.

Liu HK, Bacon WL (2005). Changes in egg production rate induced by progesterone injection in broiler breeder hens. Poult. Sci. 84: 321 327.

Liu HK, Long DW, Bacon WL (2001a) Preovulatory luteinizing hormone surge interval in old and young laying turkey hens early in the egg production period. Poult. Sci. 80: 1364-1370.

Liu HK, Long DW, Bacon WL (2001b). Concentration change patterns of luteinizing hormone and progesterone, and distribution of hierarchical follicles in normal and arrested laying turkey hens. Poult. Sci. 80: 1509-1518.

Lin HC, Wu HK, Cheng WK, Ma RS (1993). The effect of progesterone on ovulation in the Japanese quail. J. Chin. Soc. Anim. Sci. 22: 3553.

Nakada T, Koja Z, Tanaka K (1994). Effect of progesterone on ovulation 
in the hypophysectomised hen. Br. Poult. Sci. 35: 153- 156.

Onagbesan OM, Metayer S, Tona K, Williams J, Decuypere E, Bruggeman V (2006). Effects of genotype and feed allowance on plasma luteinizing hormones, follicle-stimulating hormones, progesterone, estradiol levels, follicle differentiation, and egg production rates of broiler breeder hens. Poult. Sci. 85: 1245-1258.

Palmer SS, Bahr JM (1992). Follicle stimulating hormone increases serum oestradiol-17 $\beta$ concentrations, number of growing follicles and yolk deposition in aging hens (Gallus gallus domesticus) with decreased egg production. Br. Poult. Sci. 33: 403-414.

Redshaw MR, Foiiet BK (1972). The physiology of egg yolk production in the hen, egg production and formation. Freeman, BM and Lake PE, Eds. British Poultry Science Ltd. Edinburgh.

Sun JM, Richards MP, Rosebrough RW, Ashwell CM, McMurtry JP, Coon CN (2006). The relationship of body composition, feed Intake, and metabolic hormones for broiler breeder females. Poult. Sci. 85: 1173-1184.

Tell L, Shukla A, Munson L, Thosar S, Kass P, Stanton R, Needham M, Lasley B (1999). A comparison of the effects of slow release, injectable levonorgestrel and depot medroxyprogesterone acetate on egg production in Japanese quail (Coturnix coturnix japonica). J. Avian Med. Surg. 13: 23-31.
Wilson SC, Sharp PJ (1975). Changes in plasma concentrations of luteinizing hormone after injection of progesterone at various times during the ovulatory cycle of the domestic hen (Gallus domesticus). J. Endocrinol. 67: 59-70.

Wilson SC, Sharp PJ (1976). The effects of progesterone on oviposition and ovulation in the domestic fowl (Gallus domesticus). Br. Poult. Sci. 17: 163-173.

Yu MW, Robinson FE, Robblee AR (1992). Effect of feed allowance during rearing and breeding on female broiler breeders. 1. Growth and carcass characteristics. Poult. Sci. 71: 1739-1749. 